\title{
METODE DAKWAH RASULULLAH SAW DALAM MENYEHATKAN UMMAT
}

\section{DEWI MUSTIKA}

Institut Agama Islam Negeri (IAIN) Metro

Jl. Ki Hajar Dewantara 15A Iring Mulyo, Metro Timur, Metro

Lampung 34111

e-mail : mtcistimewa@gmail.com

\begin{abstract}
Abstrak
Islam is a perfect religion and covers all aspects of life. There is no partition between one life and the other aspects of life. Islam also cannot be separated from the aspects of health and medicine in it. Even the Prophet Muhammad SAW taught us a method of treatment sourced directly from the Owner of Healing. It is through the Qur'an and the Sunnah of the Prophet Muhammad that Islam guides people towards a healthy life both physically and mentally based on the concept of divine, scientific and natural medicine. Thibbun Nabawi is not the only system of health that is systematically monolithic as some people want us to believe. This varies according to conditions, including conditions, preventive medicine, curative medicine, good mental state, spiritual wellbeing, ruqyah, health care alhmah and surgical practices so that tibbun nabawi unites with mind and body, spirit and body. Thus, the tradition of Prophet-style medicine did not stop at the teaching of medicine by the Messenger of Allah, but rather to encourage people to continue searching and experimenting with new medicine, this implies that Prophet-style medicine is not static. There is room for development and even the basis for new knowledge.
\end{abstract}

Keywords: Methode, Da'wah, Health 


\section{A. Pendahuluan}

Salah satu permasalahan kependudukan terbesar yang dihadapi pemerintah hingga saat ini adalah permasalahan kesehatan (human healt). Nampaknya permasalahan ini bukan dihadapai oleh bangsa Indonesia semata, namun permasalah kesehatan ini sudah menjadi isu global, sehingga dalam konteks permasalahan global ini, tidak adal lagi dikotomi nergara atau negara-negara yang menganggap dirinya tergolong kedalam atau kesatuan negara-negara maju, negara berkembang ataupun negara terbelakang, karena masalah kesehatan merupakan PR bersama bagi seluruh negara di seantero jagad raya ini, yang secara tidak langsung selalu menuntut untuk segera dituntaskan. Masalah kesehatan masyarakat, terutama negara-negara berkembang seperti Indonesia didasarkan kepada dua aspek utama. Yang pertama, ialah aspek fisik misalnya tersedianya sarana kesehatan dan pengobatan penyakit, sedangkan, yang kedua adalah aspek non fisik yang menyangkut prilaku kesehatan. Kedua aspek mendasar diatas mempunyai hubungan yang saling berkaitan yaitu aspek prilaku dalam menentukan sarana kesehatan dan pengobatan penyakit yang merupakan aspek non-fisik prilaku seseorang atau sekelompok orang yang kemungkinan besar sakit tapi mereka lebih memilih pergi ketempat pelayanan kesehatan ataupun memilih alternatif pengobatan lain. Penentuan pemilihan pengobatan oleh pasien dipengaruhi oleh beberapa factor untuk memenuhi keinginan dan kebutuhannya untuk sembuh dan hidup lebih sejahtera. Masalah kesehatan sekarang ini semakin menjadi bahan pembicaraan dimasyarakat, antara lain permasalah prilaku masyarakat terhadap pengobatan itu sendiri, prilaku masyarakat disini lebih difokuskan pada prilaku seseorang atau sekelompok orang yang memungkinkan besar sakit, dan mereka memilih pergi ketempat pelayanan kesehatan ataupun memilih alternatif pengobatan yang lain. Penentuan pemilihan pengobatan oleh masyarakat ini mungkin dipengaruhi oleh beberapa factor, seperti jauhnya letak tempat pelayanan kesehatan dari tempat tinggal pasien, mahalnya biaya pengobatan, ketidak puasan terhadap hasil pengobatan, sikap meremehkan terhadap suatu penyakit dan maraknya kasusu-kasus malpraktek medis akhir-akhir ini di 
Indonesia. Dewasa ini banyaknya jenis pengobatan yang bersaing untuk memberikan pelayanan terbaik untuk pasiennya. Sehingga pasien juga harus lebih selektif lagi memilih jenis pengobaan yang mana yang lebih baik untuk penyakit yang dideritanya. Ada dua jenis pengobatan yang lebih dikenal masyarakat secara umum yaitu pengobatan modern yang menggunakan tenaga medis professional atau sering disebut pengobatan ala Barat dan pengobatan tradisional atau pengobatan ala Timur.

System pengobatan tradisional banyak mendapat perhatian dari masyarakat karena system ini dalam kenyataanya masih tetap hidup dan berdampingan dengan system pengobatan modern, meskipun praktek-praktek biomedi kedokteran, makin berkembang pesat dinegar kita yang ditandai dengan munculnya pusat-pusat layanan kesehatan, baik yang dikelaola oleh pemerintah maupun oleh swasta. Pengobatan tradisional berkaitan erat dengan budaya suatu suku bangsa yang mendiami wilayah geografi tertentu. Pengobatan tradisional ini juga lazim digunakan dalam mengatasi berbagai masalah kesehatan baik didesa maupun dikota-kota besar. Perbedaan mendasar antara pengobatan modern dengan pengobatan tradisional adalah bahwa pengoabatan modern menganggap manusia lebih bersifat materialistic (darah, tulang, daging dan mengabaikan aspek spiritual) dan menggunakan obatobatan materialistic dan alat-alat yang semakin canggih untuk mendiagnosa penyakit pasiennya. Para ahli pengoabatan alternatif sering dituduh sebagai dukun, kurang ilmiah dan menolak pengobatan yang efektif dan sudah terbukti. Sebaliknya para ahli pengobatan modern dipandang sebagi pihak yang dingin dan tidak berkeprimanusiaan dan gagal dalam melihat pasien secara menyeluruh serta terlalu tergantung pada teknologi.

Perkembangan ilmu kedokteran modern (convetional medicine) saat ini memang sudah sampai ketahap yang cukup mencengangkan. Di antaranya adalah perkembangan alat-alat modern untuk mendeteksi penyakit hingga dilakukannya analisis penyakit sampai ketahap molekuler107 (DNA). Namun kita juga tidak memungkiri bahwa masih banyak hal-hal yang belum bisa disingkap oleh ilmu kedokteran modern. Misalnya, sampai saat ini belum ditemukan obat ampuh untuk membunuh infeksi kronik virus Hepatitis B. Apabila seseorang terinfeksi virus Hepatitis B secara kronik, maka sampai saat ini belum ada obat yang dapat

107 Bagian terkecil suatu senyawa yang terbentuk dari kumpulan atom yang terikat secara kimia. 
membunuh semua virus tersebut dalam tubuh. Terapi saat ini tidak bersifat menyembuhkan, tetapi tujuan pengobatan "hanya" sebatas pada penekanan perkembangbiakan virus dan pencegahan komplikasi yang lebih lanjut. Akibatnya, apabila virus Hepatiti B sudah masuk dalam tubuh maka masih dimungkinkan untuk berkembang menjadi penyakit hati kronik sampai menimbulkan komplikasi kanker hati. Buktinya di Amerika Serikat saja yang kedokteranya sangat maju infeksi Hepatitis B kronik bertanggungjawab pada 5000 kematian tiap tahun karena berbagai komplikasinya. 108 Demikian pula penyakit-penyakit lainya, dari yang terlihat 'sepele' seperti hipertensi hingga yang menakutkan seperti kanker ganas yang sudah menyebar sampai keberbagai organ tubuh lainya. Oleh karena itu, sampai saat ini para pakar kedokteran tidak henti-hentinya meneliti proses penyakit dan pengobatanya yang tepat dan efektif. Di Indonesia saja, banyak terdapat pusat-pusat penelitian dengan pembiayaan yang sangat mahal. Oleh sebab itu ilmu kedokteran merupakan ilmu yang tidak akan ada habisnya, mengingat penemuan-penemuan baru yang sangat cepat. Sehingga dari kenyataan yang ada kita sering menjumpai sebagian orang yang kemudian beralih ke pengobatan alternatif untuk mencari kesembuhan. Alasanyapun beragam ada yang beralasan karena biayanya lebih murah dan terjangkau, pengobatan medis memang masih diidentikan dengan high cost medicine (biaya tinggi) sehingga hanya terjangkau oleh sebagian kecil masyarakat. Sampai-sampai muncul suatu istilah yang cukup terkenal, yaitu "Orang miskin dilarang sakit". Ada pula yang didorong karena keinginan mencari alternatif lain setelah pengobatan medis tidak membuahkan hasil yang memuaskan. ${ }^{109}$

Apa yang dikenal oleh masyarakat luas saat ini adalah pelayanan kesehatan dengan metode Kedokteran Barat atau yang sering disebut Kedokteran Modern, yaitu paham kedokteran yang menempatkan manusia dengan segala struktur tubuhnya sebagai bagian-bagian yang terpisah dari ruhnya. Dalam metode pengobatan Barat, dokter tidak mempunyai tugas mengatasi masalah-masalah ruhiyyah. Setiap pasien yang datang akan menerima pengobatan dengan cara-cara yang dianggap rasional.110

108 Lin, K.W., Kirchner, J.T., Hepatitis B. American Academy of Family Physician, 2004, h. 75-82

109 M. Saifudin Hakim, Kemana Seharusnya Anda Berobat; Antara Pengobata Medis, Alternatif dan Thibbun Nabawi, (Solo: Wacana Ilmiah Press (WIP), 2009) h. 42

110 Muhammad Ali Toha Assegaf, Smart Healing; Kiat Hidup Sehat Menurut Nabi saw, (Jakarta: Pustaka Al-Kautsar, 2007), Cet. Ke-1, h. 7 
Semua rasa sakit harus diselesaikan dengan pengobatan tertentu yang maksudnya adalah menolong tubuh untuk kembali normal sehingga mampu mengatasi masalahnya sendiri. Mekanisme pertahanan diri dipercaya dalam bentuk yang nyata, yaitu pertahanan oleh kulit, kuku, rambut, selaput lendir, enzym-enzym, ${ }^{111}$ sel-sel darah tertentu, cairan tertentu dan lain-lain. Seorang pasien yang sakit dan menemui dokter dengan metode kedokteran Barat, akan menghadapi berbagai pertanyaan tentang gejala dan tanda, tentang riwayat penyakit masa lalunya, kemudian organ-organ akan diperiksa dengan menggunakan standar-standar yang jelas. Jika penyakit sudah diketahui dan dirumuskan, pasien akan menerima pengobatan menggunakan obat atau menerima tindakan yang telah disepakti oleh para dokter sebagai standar pengobatan. Dokter yang keluar dari mekanisme tersebut akan dianggap melanggar prinsip-prinsip pengobatan yang benar dan dapat dipertanggungjawabkan. Itu juga berarti bahwa menggunakan metode lain adalah melanggar kode etik dengan akibat bisa berupa pencabutan izin praktik dan pengucilan oleh peer group. Menggunakan metode diluar Kedokteran Barat adalah kesalahan yang berat, meskipun pasien dapat disembuhkan.112 Semua obat yang dipakai dalam pengobatan orang sakit harus melalui mekanisme yang disebut uji klinis, dengan protokol yang dapat dipertanggungjawabkan secara ilmiah.

Ilmiah disini memiliki konotasi sesuai konsep Barat, dan inilah yang membuat konsep Kedokteran Timur tidak akan diterima sejajar dengan metode pengobatan konvesional Barat, meskipun mereka memiliki prinsip sendiri yang sebenarnya juga dipertanggungjawabkan. Penemuan-penemuan kedokteran Barat diarahkan kepada penggunaan obat-obat kimia. Meskipun ekstraksi bahan-bahan alami dilakukan dengan metode yang modern, para dokter masih menganggap sebagian besar obat tradisional adalah makanan tambahan, dan menolak sebagian besar pengobatan dengan menggunakan alat ataupun tidak, yang dilakukan dengan metode lain diluar yang telah disepakati. Meskipun pada prinsipnya mereka menggunakan pengamatan yang dalam dan bersifat holistic, namun dalam prakteknya metode kedokteran Barat lebih mengutamakan pertimbangan pengobatan dengan hanya memperhatikan tanda dan gejala, dan hanya mau

111 Melekul protein yang kompleks yang dihasilkan oleh sel hidup dan bekerja sebagai katalisator dalam berbagai proses kimia ditubuh mahkluk hidup.

112 Muhammad Ali Toha Assegaf, Op. Cit., h. 10 
menerima segala pengobatan dan tindakan yang dapat diterangkan sesuai logika konvensional semata. Mereka tidak mempertimbangkan aspek spiritual dalam menyusun protokol pengobatanya. Dalam praktiknya, metode Kedokteran Barat tidak sepenuhnya berhasil menyelesaikan persoalan-persoalan kesehatan masyarakat, dan terbelenggu dengan alur pikirnya sendiri, sehingga kehilangan momentum penyehatan manusia secara utuh. Hal ini terjadi karena para pelaku kedokteran Barat banyak asyik dengan hal-hal bersifat material dan melupakan aspek spiritual, bahkan sering pula melupakan aspek kejiwaan dari para pasien. Memang hal ini tidak bisa digenalisir, akan tetapi hanya sedikit dokter yang memerhatikan aspek non-fisik tersebut, dan menurut pengamatan keadaan semakin memburuk dari hari-kehari. Banyak dokter yang kurang memperhatikan peran pasien yang sebenarnya sangat sentral dalam penyembuhan penyakitnya. Keringnya nilai-nilai spiritualitas dalam praktek kedokteran, menyebabkan misi spiritual dari para dokter lambat laun menghilang. Hal ini terjadi karena pendidikan yang didapat sejak seorang dokter menjalani pembelajaran di Fakultas Kedokteran. Dalam pendidikan kedokteran, deskripsi-deskripsi rasa sakit dan pengobatanya hanya mengacu pada pendektan rasionalitas dan tidak menyentuh aspek spiritualitas (ruhiyyah). ${ }^{113}$ Belakangan sudah mulai ada kesadaran tentang hal ini. Beberapa ahli kedokteran dinegara-negara maju mulai menyadari memelihara aspek spiritual pasien untuk mendapatkan hasil yang optimal dalam pengobatan. Dr. Larry Dossey, seorang internits ${ }^{114}$ dari Amerika Serikat, menyatakan bahwa manusia modern telah berfikir dengan cara yang terlalu canggih tentang problem kesehatanya, yang malahan tidak menyelasaikan masalah mereka. Namun perbaikan secara structural masih jauh dari harapan, dia meyakini bahwa begitu banyak problem kesehatan yang rumit dapat diselesaikan dengan cara sederhana. ${ }^{115}$ Setiap bangsa di setiap zaman memiliki ahli-ahli pengobatan dengan metodanya masing-masing. Tidak terkecuali dalam sejarah umat Islam. Sejak masa Rosul, umat Islam telah mengembangkan dunia pengobatan dengan landasan dan metoda yang khas. Yaitu pengobatan yang dibangun diatas dasar aqidah Islam dan metoda yang digariskan dalam syari'at yang kita kenal dengan istilah Thibbun Nabawi. Karena Rosulullah Muhammad

113 ibid., h.12

114 Dokter ahli penyakit dalam.

115 Larry Dossey, M.D, The Exstraodinary Healing Power Of Ordinary Things, (Jakarta: Serambi, 2007) 
SAW telah mengajarkan asas dalam pengobatan Islam yang berdasar pada wahyu. Maka merupakan tugas generasi umat Islam kini dan berikutnya untuk mengembangkan pengobatan diatas pondasi dan jalur yang telah Rasul tetapkan.

\section{B. Pengobatan}

Pengobatan awal kata dari obat (dawa') yang mempunyai makna bahan yang digunakan untuk mengurangi, menghilangkan penyakit, atau menyembuhkan seseorang dari penyakit. Jadi pengobatan adalah proses atau cara yang dilakukan tabib atau para medis untuk mengobati seorang pasien dari sakit yang dideritanya. Pengobatan sebagaimana yang ditulis oleh Everet Huges "adalah prototif dari profesi", tidaklah mengherankan bahwa pengobatan telah diketahui sejak awal oleh para ahli sosiologi sebagai suatu lapangan perhatian yang khususnya berhasil untuk menjelajah perhatian luas mereka terhadap pokok-pokok seperti pekerjaan dan pembagian kerja didalam masyarakat.

1. Tujuannya dan Prinsip-prinsip Pengobatan

a. Tujuan Pengobatan didalam Islam

1) Pembersih dosa

2) Kesembuhan

3) Keridhoan

4) Tawakkal

5) Baik sangka kepada Allah

6) Bertambah dekat dengan Allah

7) Senantiasa Bertobat

8) Meninggal dalam Husnul Khatimah

b. Prinsip-prinsip Pengobatan Islam

1) Prinsip Keyakinan, yaitu bahwa yang menyembuhkan adalah Allah Swt. Sebagaimana disebutkan dalam Al-Qur'an :

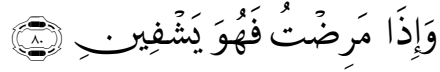

Artinya : "dan apabila aku sakit, Dialah yang menyembuhkan Aku". [As Syu'ara' : 80]

2) Menggunakan obat yang halal dan thoyyib. "Sesungguhnya Allah menurunkan penyakit dan obatnya dan menjadikan setiap penyakit pasti ada obatnya. Maka berobatlah kalian, tapi jangan dengan yang haram." ( HR. Abu Dawud)

3) Tidak membawa mudarat yang mencacatkan tubuh 
4) Tidak berbau tahayul, khurafat dan bid'ah

5) Mencari yang lebih baik

6) Mengambil sebab melalui ihtiar

\section{Macam-macam Pengobatan}

\section{Pengobatan Modern}

Di dalam suatu ilmu kesehatan untuk menyembuhkan suatu penyakit ada dua macam pengobatan, yaitu pengobatan modern dan pengobatan tradisional. Pengobatan-pengobatan ini sangat berbeda satu sama lain. Pengobatan modern adalah pengobatan yang dilakukan dengan cara-cara modern atau ilmiah atau telah diuji cobakan dengan sebuah penelitian dan dapat dipertanggungjawabkan. Namun, dari cara pembuatan, obat modern memiliki sedikit keunggulan karena dibuat dengan mesin dan pada umumnya dilakukan secara terukur dan melalui proses percobaan yang terkontrol. Dengan demikian, sterilisasi atau faktor kebersihan obat modern jauh lebih terjaga. Obat-obatan modern juga dibuat dengan menambahkan beberapa zat kimia sehingga bukan mustahil akan ada efek samping setelah mengkonsumsinya obat jenis ini. Pengobatan modern relatif lebih mahal karena bahan baku obat-obatannya sangat mahal dan harganya sangat tergantung pada banyak komponen.

\section{Pengobatan Alternatif}

Obat Tradisional atau alternatif adalah obat yang dibuat dari tumbuhan yang diolah dengan cara yang sangat sederhana dan membutuhkan tenaga manusia yang sangat besar. Keunggulan yang diperoleh dalam menggunakan ramuan tradisional, yaitu pada umumnya, harga ramuan tradisional lebih murah jika dibandingkan dengan obat-obatan buatan pabrik, bahan ramuan tradisional sangat mudah didapatkan di sekitar lingkungan, bahkan dapat ditanam sendiri untuk persediaan keluarga, pengolahan ramuannya juga tidak rumit, sehingga dapat dibuat di dapur sendiri tanpa memerlukan peralatan khusus dan biaya yang besar. Penggunaan ramuan tradisional memiliki efek samping negatif yang sangat kecil jika dibandingkan dengan obat-obatan medis modern. Hal ini dikarenakan, bahan baku ramuan tradisional sangat alami atau tidak bersifat sintetik. Meskipun demikian, obat herbal yang baru tetap harus melewati uji klinis yang sama dengan obat-obatan sintetik. Selama mengikuti takaran yang dianjurkan, proses pembuatannya higienis, dan cara penyimpanan yang baik, maka efek samping negatif ramuan tradisional ini tidak perlu dikhawatirkan. Hubunganan diantara pengobatan alternatif 
dengan pengobatan modern bukanlah hubungan yang bersaing. Pengobatan kedua-duannya hidup saling berdampingan dan bersama-sama menyediakan pilihan pengobatan untuk bermacammacam penyakit. Dalam bidang alternatif ada sifat yang bisa menyediakan bidang medikal dan sebaliknya. Jadi untuk pemilihan obat yang baik pilihlah obat yang berkhasiat seperti obat Tradisional tapi tetap terjaga mutu dan kebersihannya seperti obat Modern. Realita bahwa hampir sebagian besar orang yang menderita sakit akan melakukan usaha untuk menghilangkan atau mengurangi rasa sakit yang dideritanya. Namun tidak sedikit dari orang yang melakukan usaha penyembuhan tersebut gagal mematuhi prosedur terapi yang disarankan petugas kesehatan dan farmasi, sehingga berakibat pada kegagalan terapi maupun timbulnya efek samping yang lebih membahayakan dari sakit yang dideritanya. Perilaku ketidakpatuhan masyarakat dalam proses terapi ini pada umumnya terkait dengan aturan pemakaian obat, baik bagi mereka yang menggunakan resep dokter maupun konsumen yang langsung membeli obat ke apotek atau toko obat untuk menentukan pilihannya. Penyebabnya tidak lain adalah ketidakfahaman terhadap apa yang sesungguhnya terjadi pada proses terapi atau pengobatan. Diantara macam-macam pengobatan alternatif modern saat ini adalah :

a. Ruqyah (mantera)

Makna ruqyah secara terminologi adalah al-'udzah (sebuah perlindungan) yang digunakan untuk melindungi orang yang terkena penyakit, seperti panas karena disengat binatang, kesurupan, dan yang lainnya. Secara terminologi, ruqyah terkadang disebut pula dengan 'azimah. Al-Fairuz Abadi berkata: "Yang dimaksud 'azimah-'azimah adalah ruqyah-ruqyah. Sedangkan ruqyah yaitu ayat-ayat Al-Qur`an yang dibacakan terhadap orang-orang yang terkena berbagai penyakit dengan mengharap kesembuhan."116 Adapun makna ruqyah secara etimologi syariat adalah doa dan bacaan-bacaan yang mengandung permintaan tolong dan perlindungan kepada Allah Subhanahu wa Ta'ala untuk mencegah atau mengangkat bala/penyakit. Terkadang doa atau bacaan itu disertai dengan sebuah tiupan dari mulut ke kedua telapak tangan atau anggota tubuh orang yang meruqyah atau

116 Ahmad Warson Munawwir, Al Munawwir : Kamus Arab-Indonesia, (Surabaya: Pustaka Progressif), h. 23 
yang diruqyah. ${ }^{117}$ Tentunya ruqyah yang paling utama adalah doa dan bacaan yang bersumber dari Al-Qur`an dan As-Sunnah. ${ }^{118}$

b. Al Hijamah (bekam)

Al Hijamah berasal dari istilah Bahasa Arab yang berarti pelepasan darah kotor dan bukan $\mathrm{Al} \mathrm{Fashd} \mathrm{(pembuang} \mathrm{darah).} \mathrm{atau}$ dalam bahasa Inggris disebut dengan Cupping dan dalam bahasa melayu dikenal dengan istilah Bekam. Di Indonesia kita kenal denan istilah Kop atau Cantuk. Bekam merupakan suatu teknik pengobatan Sunnah Rasulullah Saw yang telah lama dipraktekkan oleh manusia sejak zaman dahulu kala, kini pengobatan ini dimodernkan dan mengikuti kaidah - kaidah ilmiah, dengan menggunakan suatu alat yang praktis dan efektif sera tanpa efek samping. Teknik pengobatan bekam adalah suatu proses membuang darah kotor (toksid-racun yang berbahaya dari dalam tubuh, melalui permukaan kulit. Toksid/toksin adalah endapan racun/zat kimia yang tidak dapat diuraikan oleh tubuh kita. Toksin ini berada pada hampir setiap orang. Toksin-toksin ini berasal dari pencemaran udara, maupun dari makanan yang banyak mengandung zat pewarna, zat pengembang, penyedap rasa, pemanis, pestisida sayuran dll.

\section{Al-Thibbun Al-Nabawi}

\section{Petunjuk Al Qur'an Tentang Pengobatan}

Banyak ayat Al-Qur'an yang mengisyaratkan tentang pengobatan karena Al-Qur'an itu sendiri diturunkan sebagai penawar dan rahmat bagi orang-orang mukmin.

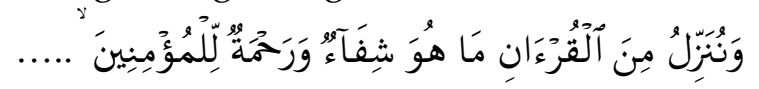

Artinya : "Dan kami turunkan dari Al Quran suatu yang menjadi penawar dan rahmat bagi orang-orang yang beriman ....."(Al Isra' : 82)

Menurut para ahli tafsir bahwa nama lain dari Al-Qur'an yaitu Asy-syifa yang artinya secara terminologi adalah obat penyembuh.

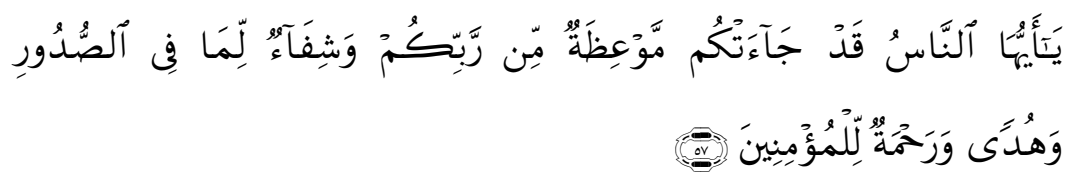

117 Ceramah Asy-Syaikh Shalih bin 'Abdul 'Aziz Alus-Syaikh yang berjudul Ar-Ruqa wa Ahkamuha oleh Salim Al-Jaza iri, hal. 4

118 Ibid, hal. 5 
Artinya : “Hai manusia, Sesungguhnya Telah datang kepadamu pelajaran dari Tuhanmu dan penyembuh bagi penyakit-penyakit (yang berada) dalam dada dan petunjuk serta rahmat bagi orang-orang yang beriman".(QS Yunus:57)

Disamping Al-Qur'an mengisyaratkan tentang pengobatan juga menceritakan tentang keindahan alam semesta yang dapat kita jadikan sumber dari pembuat obat-obatan.

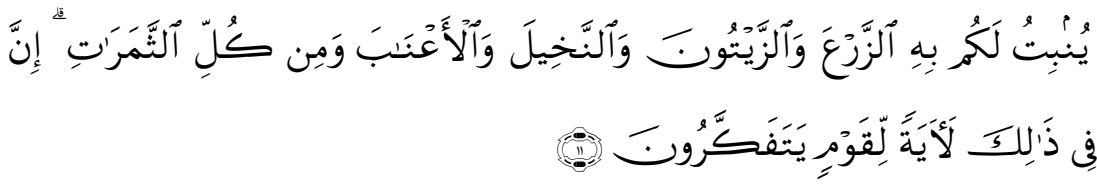

Artinya : "Dia menumbuhkan bagi kamu dengan air hujan itu tanam-tanaman; zaitun, korma, anggur dan segala macam buahbuahan. Sesungguhnya pada yang demikian itu benar-benar ada tanda (kekuasaan Allah) bagi kaum yang memikirkan.(QS AnNahl:11)

\section{Metode Pengobatan Para Rasul Sebelumnya}

a. Nabi Isa AS

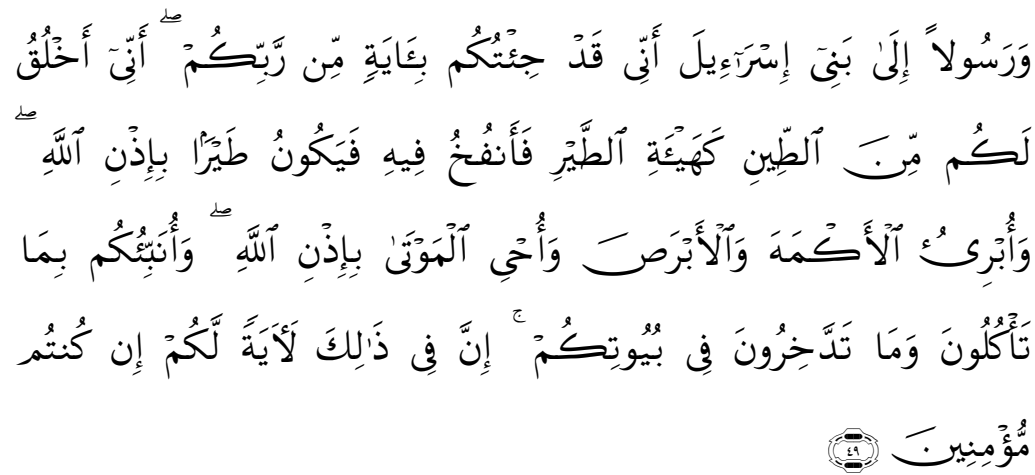

“Dan (sebagai) Rasul kepada Bani Israil (yang Berkata kepada mereka): "Sesungguhnya Aku Telah datang kepadamu dengan membawa sesuatu tanda (mukjizat) dari Tuhanmu, yaitu Aku membuat untuk kamu dari tanah berbentuk burung; Kemudian Aku meniupnya, Maka ia menjadi seekor burung dengan seizin Allah; dan Aku menyembuhkan orang yang buta sejak dari lahirnya dan orang yang berpenyakit sopak; dan Aku menghidupkan orang mati dengan seizin Allah; dan Aku kabarkan kepadamu apa yang kamu makan dan apa yang kamu simpan di rumahmu. Sesungguhnya pada yang demikian itu adalah suatu 
tanda (kebenaran kerasulanku) bagimu, jika kamu sungguhsungguh beriman. (Ali Imron : 49)

Menurut para mufassir, Nabi Isa mengobati penyakit buta dan kusta dengan cara di usap dengan tangan nya, mata yang buta dan anggota tubuh yang terkena kusta dengan izin Allah melalui mukjizatnya maka seketika itu sembuh.

\section{b. Nabi Musa AS}

Nabi Musa tidak lepas dari sifat kemanusiaannya yang merupakan sunnatulloh yaitu sakit. Beliau pernah sakit lalu memetik sehelai daun yang diniatkan sebagai obat yang hakikatnya Allah menyembuhkan kemudian di tempelkannya daun tersebut pada anggota tubuh yang sakit, karena mukjizatnya seketika itu sembuh. Dan kedua kali nya beliau sakit kemudian memetik sehelai daun secara spontanitas tanpa diniatkan sebagai obat yang hakikatnya Allah Sang Penyembuh maka ketika itu sakitnya tidak sembuh.

c. Nabi Muhammad SAW

Nabi Muhammad sebagai Rasul yang diperintahkan Allah untuk menyampaikan wahyu kepada umat-nya tidak lepas tingkah lakunya dari Al-Qur'an karena beliau dijadikan suri tauladan yang baik untuk semua manusia. Firman Allah :

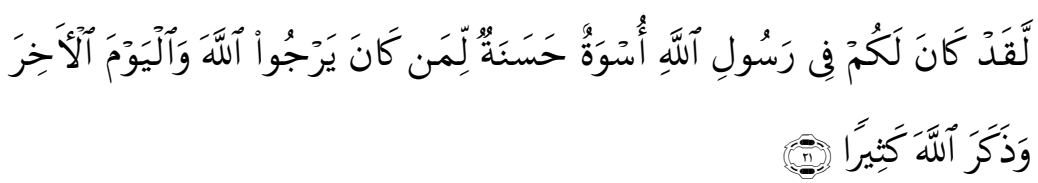

Artinya : "Sesungguhnya Telah ada pada (diri) Rasulullah itu suri teladan yang baik bagimu (yaitu) bagi orang yang mengharap (rahmat) Allah dan (kedatangan) hari kiamat dan dia banyak menyebut Allah". (Al Ahzab : 21)

Imam Ali berkata : "Sesungguhnya semua tingkah laku Nabi Muhammad SAW adalah Al-Qur'an". Beberapa metoda pengobatan yang dilakukan Rasulullah :

1. Ruqyah. Ada 3 cara ruqyah yang dilakukan oleh Nabi : 
a. Nafats. Yaitu membacakan ayat Al-Qur'an atau doa kemudian di tiupkan pada kedua telapak tangan kemudian di uasapkan keseluruh badan pasien yang sakit. Dalam suatu riwayat bahwasanya Nabi Muhammad SAW apabila beliau sakit maka membaca Al-muawwidzat yaitu tiga surat Al-Qur'an yang diawali dengan ta'awudz yaitu surat $A n$ Naas, Al Falaq, dan Al ikhlas kemudian di tiupkan pada kedua telapak tangannya lalu diusapkan keseluruh badan.

b. Air liur yang ditempelkan pada tangan kanannya. Diriwayatkan oleh Bukhari-Muslim : bahwasanya Nabi Muhammad SAW apabila ada manusia yang tergores kemudian luka, maka kemudian beliau membaca doa kemudian air liurnya ditempelkan pada tangan kanannya, lalu di usapkan pada luka orang tersebut. Inilah doa nya:

اللهم رب الناس مذهب البأس اشف الثاء الت الثافى لاشافي إلأنت شفاءلايغادر سقما. [رواه البخاري]

Artinya : Ya Allah, Rabbnya manusia, Zat yang menyembuhkan penyakit. Sembuhkanlah ia, Engkaulah Zat pemberi kesembuhan. Tidak ada yang dapat menyembuhkan melainkan Engkau. Kesembuhan yang tidak lagi meninggalkan sakit." 119

c. Meletakkan tangan pada salah satu anggota badan. Nabi Muhammad SAW pernah memerintahkan Utsman bin Abil Ash yang sedang sakit dengan sabdanya : "letakkanlah tanganmu pada anggota badan yang sakit kemudian bacalah "Basmalah 3x" dan "A'udzu bi-izzatillah waqudrotihi minsyarrima ajidu wa uhajiru $7 x^{\prime \prime}$.

2. Do'a Mukjizat. Banyak doa-doa kesembuhan yang di ajarkan oleh Nabi Muhammad SAW kepada umat nya, salah satunya :

$$
\text { البخاري] الباس رب الناس بيدك الثفاء لا كاشف له إلا أنت ـ [رو اه }
$$

Artinya : "Hilangkanlah penyakit ini wahai Rabbnya manusi, ditangan-Mu kesembuhan itu. Tidak ada yang menyembuhkannya melainkan diri-Mu."120

3. Dengan memakai madu. Sebagaimana Allah berfirman dalam surat An Nahl : 69 bahwa madu Allah jadikan

${ }^{119}$ H.R. Al Bukhari, No. 5410
${ }^{120}$ H.R. Al Bukhari, No. 2192 
sebagai obat maka Rasulullah menggunakan madu untuk mengobati salah satu keluarga sahabat yang sedang sakit. Dalam satu riwayat, ada sahabat yang datang kepaa Rasulullah memberitahukan anaknya sedang sakit, kemudian Nabi menyuruh meminumkan anaknya madu sambil membaca doa.

4. Bekam. Berbekam termasuk pengobatan yang diajarkan Rasulullah SAW, bahkan Rasulullah SAW pernah melakukan bekam dan memberikan upah kepada tukang bekam.

\section{Klasifikasi at Thibbun an Nabawi}

Thibbun nabawi Preventif (Pencegahan) : klasifikasi tradisi yang berhubungan dengan pengobatan tergantung pada kondisi ilmu pengetahuan serta perubahannya mengikuti ruang dan waktu. Jalaluddin al Suyuti dalam sebuah buku tentang thibbun nabawi dan membagi pengobatan menjadi 3 jenis : tradisional, spiritual dan pencegahan. Kebanyakan thibbun nabawi merupakan pencegahan. Konsepnya tergolong ilmu pengetahuan yang sangat maju pada masa Rasulullah serta diyakini merupakan ilham yang turun langsung dari Allah. Al Suyuti menguraikan langkah medis preventif seperti makan dan olahraga. Langkah medis preventif lainya yang diajarkan didalam hadits meliputi : karantina untuk penderita wabah hijr sihhi, melarang urinasi pada air yang tenang atau tidak mengalir, penggunaan sikat gigi, siwaak, perlindungan rumah pada malam hari dari kebakaran dan penyakit pes, meninggalkan sebuah Negara karena air dan iklimnya, kesehatan mental dan pernikahan, kesehatan pernikahan dan seksual, control diet untuk mencegah berat badan berlebihan, menjaga kebersihan dan mencegas najis.

Thibbin nabawi Spiritual : Penelitian thibbun nabawi menyatakan ada aspek-aspek spiritual dari penyembuhan dan pemulihan. Do'a, pembacaan Al Qur'an dan mengingat Allah sebagai satu-satunya sesembahan. Penyakit psikosomatik dapat merespon pendekatan spiritual. Penggunaan ruqyat (surat al fatihah, al mu'awadhatain) jatuh diantara proses penyembuhan fisik dan spiritual. Bagian penyembuhan dari ruqyat bisa difahami dalam istilah modern : bahwa jiwa mampu mengendalikan mekanisme kekebalan tubuh yang mencegah penyakit.

Thibbun nabawi Kuratif (Penyembuhan) : Ibnul Qayim al Jauziyah menyebutkan banyak penyakit yang tindakan medisnya direkomendasikan dari thibbun nabawi. Penyakit-penyakit oleh 
thibbun nabawi dapat diobati dengan pengobatan alami : humma (demam), jarh (luka), sa'a (epilepsy) dan lain-lain. Perawatan medis yang disebutkan adalah madu, air dingin untuk demam, al laban, al habba al sauda. Sedangkan perawatan bedah yang disebutkan adalah al hijamah (bekam), al kayy (kauterisasi), qatiu al uruuq wa al kayy (veneseksi dengan kauterisasi)

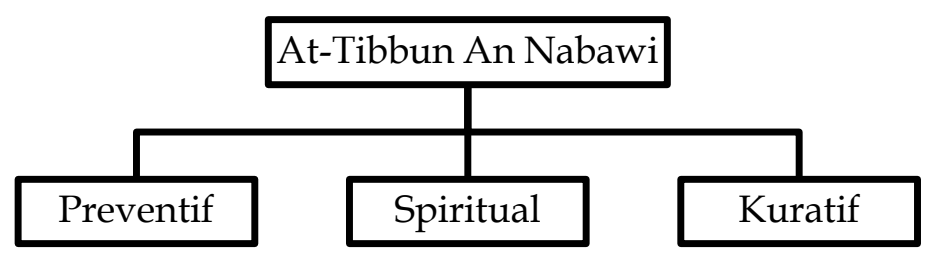

Klasifikasi At Thibbun an Nabawi

\section{E. Metode Dakwah Rasulullah saw dalam Menyehatkan Ummat}

Kata metode berasal dari bahasa latin methodus yang berarti cara. Dalam bahasa Yunni, methodhus berarti jalan atau cara. Sedangkan dalam bahasa Inggris method dijelaskan dengan metode atau cara. ${ }^{121}$ Kata metode telah menjadi bahasa Indonesia yang memiliki pengertian "Suatu cara yang bisa ditempuh atau cara yang ditentukan secara jelas untuk mencapai dan meyelesaikan suatu tujuan, rencana system, tata pikir manusia". ${ }^{122}$

Abdul Kadir Munsy, mengartikan metode sebagai cara untuk menyampaikan sesuatu. ${ }^{123}$ Sedangkan dalam metodelogi pengajaran ajaran Islam disebutkan bahwa metode adalah "Suatu cara yang sistematis dan umum terutama dalam mencari kebenaran Ilmiah".124 Dalam kaitanya dengan pengajaran Islam, maka pembahasan selalu berkaitan dengan hakikat penyampaian materi kepada peserta didik agar dapat diterima dan dicerna dengan baik.

\footnotetext{
Cahaya, 1983, h. 17

122 M. Syafaat Habib, Buku Pedoman Dakwah, Jakarta: Wijaya, 1992, Cet. I, h. 160

${ }^{123}$ Abdul Kadir Munsy, Metode Diskusi dalam Dakwah, Surabaya: Al Ihklas, 1982, Cet. I, h. 29

124 Soeleman Yusuf, Slamet Suesanto, Pengantar Pendidikan Sosial, Surabaya: Usaha Nasional, 1981, h. 38
}

121 Soejono Soemargono, Filsafat Ilmu Pengetahuan, Yogyakarta: Nur 
Metode Adalah cara yang sistematis dan teratur untuk pelaksanaan suatu atau cara kerja. ${ }^{225}$ Sementara itu dalam komunikasi metode dakwah ini lebih dikenal sebagai approach, yaitu cara-cara yang dilakukan oleh seorang da'i atau komunikator untuk mencapai suatu tujuan tertentu atas dasar hikmah dan kasih sayang. ${ }^{126}$ Dengan kata lain, pendekatan dakwah harus bertumpu pada suatu pandangan human oriented menetapkan penghargaan yang mulia pada diri manusia. Hal itu didasari karena Islam sebagai agama salam yang menebarkan rasa damai menempatkan manusia pada prioritas utama artinya penghargaan manusia itu tidaklah dibeda-bedakan menurut ras, suku dan lain sebagainya. Metode dakwah adalah jalan atau cara yang dipakai juru dakwah untuk menyampaikan ajaran materi dakwah (Islam). Dalam menyampaikan suatu pesan dakwah, metode sangat penting peranannya, suatu pesan walaupun baik tetapi disampaikan lewat metode yang tidak benar, pesan itu bisa saja ditolak oleh si penerima pesan. Dalam Ilmu Komunikasi ada jargon "the Methode is Message". Maka dari itu kejelian dan kebijakan juru dakwah dalam memilih dalam memakai metode sangat mempengaruhi kelancaran dan keberhasilan dakwah, Allah SWT berfirman :

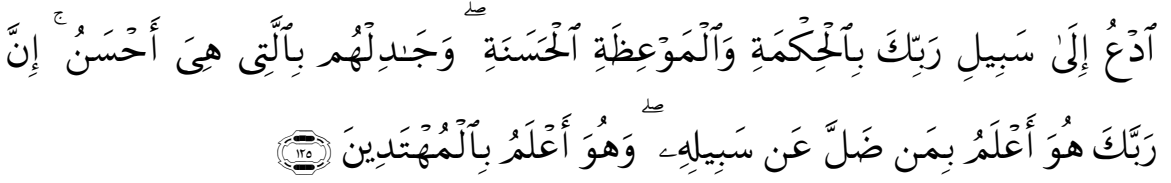

Artinya : "Serulah (manusia) kepada jalan Tuhan-mu dengan hikmah ${ }^{127}$ dan pelajaran yang baik dan bantahlah mereka dengan cara yang baik. Sesungguhnya Tuhanmu Dialah yang lebih mengetahui tentang siapa yang tersesat dari jalan-Nya dan Dialah yang lebih mengetahui orangorang yang mendapat petunjuk." (An Nahl : 125)

Dari ayat tersebut secara garis besar ada tiga pokok metode (tharigah) dakwah yaitu :

1. Hikmah, yaitu berdakwah dengan memperhatikan situasi dan kondisi sasaran dakwah dengan menitik beratkan pada

125 P. A. Partanto, M. Dahlan Al Barri, Kamus Ilmiah Populer, Surabaya: Arloka, 1994, h. 461

126 Toto Tasmara, Op.cit, h. 43

127 Hikmah: ialah Perkataan yang tegas dan benar yang dapat membedakan antara yang hak dengan yang bathil. 
kemampuan mereka sehingga dalam menjalankan ajaranajaran Islam selanjutnya mereka tidak lagi merasa terpaksa atau keberatan.

2. Mauidhoh hasanah, yaitu berdakwah dengan memberikan nasihat-nasihat atau menyampaikan ajaran-ajaran Islam dengan rasa kasih sayang, sehingga nasihat dan ajaran Islam yang disampaikan itu dapat menyentuh hati mereka.

3. Mujadalah, yaitu berdakwah dengan cara betukar pikiran dan membantah dengan cara yang sabaik-baiknya dengan tidak memberikan tekanan-tekanan dan tidak pula dengan menjalankan yang menjadi sasaran dakwah. ${ }^{128}$

Dalam abad informasi sekarang ini dakwah tidak bisa tidak harus semaksimal mungkin menggunakan media massa modern seperti Radio, TV, Internet, Pers, dan sebagainya karena hal ini tidak ada yang dapat membantah kemampuan media massa ini dalam penyebaran suatu agama. Inilah beberapa sarana yang bisa digunakan untuk penyampaian dakwah kepada objek dakwah. Dengan mengoptimalkan wasilah-wasilah modern diatas dakwah akan lebih cepat disampaikan karena media cetak, media audio visual ataupun yang visual dan audio telah menjadi konsumsi massal masyarakat. Untuk itu akan sangat efektif apabila berdakwah melalui jalur media tersebut selain itu juga seorang da'i bisa menggunakan wasilah sebagai kendaraan dakwahnya diantara

\section{a. Media Pendidikan}

Wasilah pendidikan sangat berperan penting dalam pencapaian dakwah. sehingga harus mendapat perhatian khusus dari seorang da'i.

b. Media Politik

Dalam dunia politik saat ini ada istilah partai politik yang diakui atau tidak menjadi sebuah pemikiran bagi umat Islam dalam menjalankan dakwahnya, akan tetapi ada dua syarat dalam mengunakan wasilah ini :

1) Harus mengakui Islam, baik akidah maupun syari'at serta tidak memusuhi atau menolaknya, meskipun partai itu memiliki ijtihad khusus dalam pemahamannya dibawah pancaran dasar-dasar pokok ilmiah yang telah ditetapkan.

2) Tidak berbuat untuk kepantingan kelompok-kelompok yang memusuhi Islam dan umatnya, apapun nama dan dimanapun tempatnya. 
Dengan demikian tidak ada satu partaipun boleh didirikan untuk menyeru kepada atheisme, liberthinisme atau anti agama atau menyerang semua agama samawi secara keseluruhan, atau agama Islam khususnya, atau meremehkan kesucian Islam, baik akidah, syari'ah, Al Qur'an, maupun Nabinya. ${ }^{129}$

c. Media Ekonomi

Ekonomi sangatlah urgen dalam dakwah Islam, sehingga ia menjadi salah satu wasilah sangat efektif dalam dakwah. seperti wasilah yang lain dalam mencapi tujuan dakwah tidak diperbolehkan menggunkan wasilah yang haram, maka ekonomi disini adalah ekonomi Islam. Ada tiga landasan ekonomi Islam untuk menjadi standar operasional yaitu Ekonomi Ilahiah, Ekonomi berbasis akhlak, dan ekonomi berbasis kemanusiaan dan pertengahan. ${ }^{130}$

d. Media Sosial

Dakwah dengan wasilah sosial sangat berpengaruh besar, karena dakwah model inilah yang paling berkesan, dan dengan wasilah inilah para misionaris berhasil memurtadkan ummat Islam. Maka akan terwujudlah keberpihakan da'i pada mustad'afin. Para juru dakwah terketuk hatinya untuk melakukan usaha-usaha sosial untuk kepentingan kaum tertindas di daerahnya semisal, kasus penggusuran tanah, pencemaran lingkungan, penggusuran nelayan dan petani. Rasa empati sosial merupakan prasyarat bagi juru dakwah yang menggunakan pendekatan transformatif. ${ }^{131}$

e. Media Seni Budaya

Islam adalah agama realistis dan positif, karena ia berinteraksi dengan manusia secara menyeluruh, jasmaninya, ruhaniyahnya, akal dan perasaanya. Dan Islam menuntut manusai agar ia memenuhi seluruh kebutuhannya selama dalam batas-batas yang adil dan seimbang. Apabila olahraga itu berfungsi untuk menyegarkan tubuh, ibadah untuk menyegarkan ruhani, ilmu untuk menyegarkan akal, maka seni berfungsi untuk menyegarkan

129 Sulaiman bin Shalih Al Khuraisi, Pemikiran DR. Yususf Al Qaradhawi dalam Timbangan, Pustaka As syafi'I, 2003, cet. Ke-I. h.310

130 Yususf Al Qaradhawi, Peran Nilai dan Moral dalam Perekonomian Islam, Rabbani Press, 1997, ct. ke I, h.23

131 Khamami Zada, "Dakwah Transformatif: Mengantar Da'i sebagai Pendamping Masyarakat" dalam, http://www.lakpesdam.or.id/publikasi/116/dakwahtransformatifmengantar-dai-sebagai-pendamping-masyarakat, (download : 7.43 wib, 22 Maret 2015) 
perasaan. Dan yang dimaksud seni disini adalah seni mengangkat martabat manusia, bukan yang menjatuhkannya. ${ }^{132}$

d. Media (wasilah) Jihad

Islam memerintahkan jihad kepada kaum muslimin, sebagaimana memerintahkan shalat, zakat, puasa dan haji. Jihad adalah salah satu tanda keimanan seseorang, jihad merupakan keharusan hidup dan tuntutannya. Sebab Islam tidak mewajibkannya kecuali untuk membela diri dan sebagai jaminan bagi keberlangsungan dakwah, sebagai pencegah terjadinya fitnah dan sebagai alat untuk menolong orang-orang yang lemah, serta sebagai pelajaran bagi orang-orang yang sombong. Seluruh kaum muslimin sepakat, baik orang yang masih bertaklid, orang salaf maupun kholaf, bahwa jihad adalah fardhu kifayah untuk ummat islam demi menebarkan dakwah, dan fardhu 'ain demi mempertahankan diri da'i serangan orang-orang kafir. ${ }^{133}$

e. Media Kesehatan

Fisik yang kuat dan sehat merupakan modal utama agar dapat menunaikan tugas dengan baik. Tugas dakwah membutuhkan kemampuan fisik para da'inya begitupun juga mad'unya. Tugas yang penuh tantangan, ancaman, teror, intimidasi dan berbagai tipudaya haruslah ditopang dengan kebugaran tubuh, kekuatan tenaga, ketahanan, ketangkasan, kelincahan dan keuletan adalah keniscayaan bagi kader dakwah demi tegaknya Islam yang kaffah. mereka yang sakit-sakitan cenderung tidak bugar, lemah daya kerjanya akan membebani sesamanya. Ia tidak sanggup memikul beban dakwah yang berat dan panjang. Salah satu dakwah Rasulullah yang belum banyak terungkap oleh para da'i yakni dalam masalah kesehatan, yang biasanya hanya dilakukan oleh paramedis tanpa ada unsur-unsur da'awinya ataupun unsur ilahiyahnya yang dilakukan kepada pasien.

Dalam agama Islam kesehatan merupakan penjabaran yang nyata dari rahmat kasih sayang Allah yang meliputi segala-galanya dan mamadai risalah Nabi Besar Muhammad SAW, dan itulah sesungguhnya wajah dari Islam. Dalam hal ini Rasulullah memberikan toriqoh dalam membangun umat sehat jasmani dan rohani yang tidak lepas dari dakwahnya para dai dan kalangan medis baik itu dari pengobatan alternatif yang notabenya dan subtansi yang digunakan dalam pengobatan adalah sesuai dengan

132 op.cit, Yusuf Al Qaradhawi, h.232

${ }^{133}$ Musthafa Malaikah, Manhaj dakwah Yusuf Al Qaradhawi Harmoni antara Kelembutan dan Ketegasan, Pustaka al kautsar, 2001, cet. Ke-I h. 106 
yang syariatkan Islam dalam bidang kedokteran, diantara medel dakwah nabi dalam menyehatkan ummat meliputi:

1) Metode Pengobatan Ilahiyyah

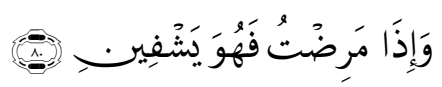

Artinya : "Dan apabila Aku sakit, dialah yang menyembuhkan aku." (As Syu'ara: 80)

Memantapkan keimanan-ketaqwaan pada Allah swt. Hanya kepada Allah kita menyembah dan hanya kepada-Nya kita memohon pertolongan. Seorang hamba harus bekerja keras namun ujung dari kerja itu adalah tawakkal pada kehendak Allah. Keimanan-ketaqwaan seperti ini akan membuat hati tenangtenteram, tidak gelisah dan terlanda ketakutan. Di sinilah makna janji Allah yang banyak terkandung dalam al Qur'an: 'Barang siapa yang benar-benar beriman dan beramal shaleh maka akan memperoleh berkah dari Allah dan hatinya akan terhindarkan dari rasa ketakutan dan kekecewaan'. Hati menjadi nyaman dan bahagia. Dari sisi Ilmu Kedokteran sudah terbukti bahwa jiwa yang gelisah merupakan stessor yang menginduksi produksi melimpah berbagai hormon yang memberi efek negatif bila berlebihan, seperti adrenalin dan kortisol. Ibadah mahdhah yang dilakukan Nabi secara intensif ternyata memiliki banyak peranan dalam menyehatkan tubuh manusia. Rahasia Shalat yang telah terungkap antara lain membantu proses pelancaran aliran darah untuk menjangkau ke organ otak, bagian yang paling tersembunyi sekalipun. Di dalam otak manusia memang ada area yang penyaluran aliran darah ke sana amat minim dan baru bisa maksimal jika melakukan gerak sujud. Dengan sujud maka otak akan memperoleh asupan makanan yang baik via aliran darah sehingga fungsinya makin optimal. Puasa jelas memiliki peran besar pada berbagai organ, dan yang mutahir diberitakan adalah terjadinya produksi sitokin melatonin yang membuat orang menjadi semakin baik kekebalannya, tidur lebih nyaman, dan memperkecil resiko terkena kangker. Justru usus yang tidak kenyanglah yang akan memproduksi sitokin itu secara baik. Dzikir mengucapkan kalimah toyyibah diketahui akan membuat saluran pernapasan terbuka secara maksimal sehingga lebih memperlancar aliran udara ke dalam paru-paru manusia sehingga membantu proses oksigenisasi.

2) Metode Pengobatan Ilmiah

Prinsip ini menunjukkan bahwa pengobatan yang dilakukan harus ilmiah. Yang dimaksudkan ilmiah dalam hal ini dapat 
diukur. Seorang dokter dalam mengembangkan pengobatannya, dapat diukur kebenaran metodologinya oleh dokter lainya. Sementara seorang dukun dalam mengobati pasiennya, tidak dapat diukur metode yang digunakannya oleh dukun yang lainya. System ini tidak dapat diukur disebut tidak ilmiah dan tidak metodologist.

3) Metode Pengobatan alamiah

Yang dimaksud pengobatan alamiah disini adalah kita menggunakan obat-obat yang mengandung unsur-unsur alamiah yang biasa kita kenal dengan obat herbal. Allah swt berfirman :

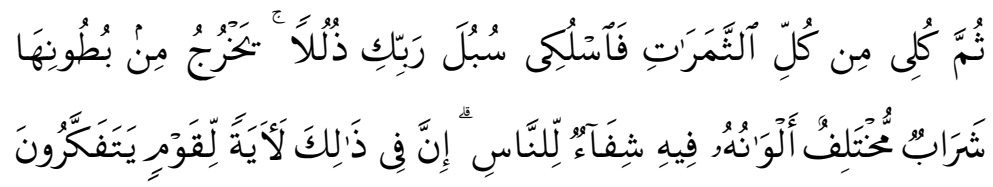

Artinya : "Kemudian makanlah dari tiap-tiap (macam) buah-buahan dan tempuhlah jalan Tuhanmu yang Telah dimudahkan (bagimu). dari perut lebah itu ke luar minuman (madu) yang bermacam-macam warnanya, di dalamnya terdapat obat yang menyembuhkan bagi manusia. Sesungguhnya pada yang demikian itu benar-benar terdapat tanda (kebesaran Tuhan) bagi orang-orang yang memikirkan." (An Nahl : 69)

Sebagaimana dalam hadits yang diriwayatkan oleh Abu Dawud dengan sanad hasan berdasarkan berbagai riwayat pendukungnya, dari Abu Darda' ra Nabi bersabda :

$$
\begin{aligned}
& \text { عن أم الدرداء رضي الله عنها أن النبي صلى الله عليه وسلم قال: " إن الله خلق الداء والدواء }
\end{aligned}
$$

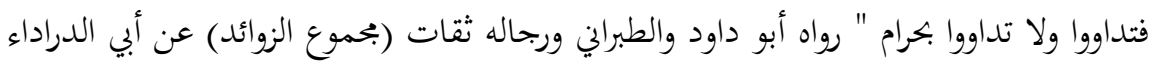

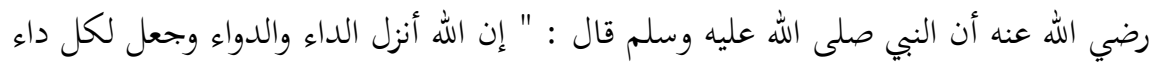

$$
\begin{aligned}
& \text { دواء فتداووا ولا تداووا بحرام " رواه أبو داود الن عليه }
\end{aligned}
$$

“Dari Ummu Darda' r.a bahwasanya Nabi saw bersabda : Sesungguhnya Allah menurunkan menciptakan obat untuk setiap penyakit, karena itu hendaklah kalian berobat, tetapi jangan berobat dengan sesuatu yang haram". (HR. Abu Dawud dan Tabrani). Dari Abi Darda'r.a bahwasanya Nabi saw bersabda : "Sesungguhnya Allah menurunkan setiap penyakit dan 
menjadikan obatnya, maka berobatlah dan janganlah kalian berobat dengan sesuatu yang haram."(HR. Abu Dawud) ${ }^{134}$

Berobat tidaklah mengurangi nilai tawakal. Sebaliknya, mengupayakan sebab-sebab merupakan kewajiban syar'i. Hakikat tawakal adalah kesungguhan dalam menggantungkan hati kepada Allah, seraya melaksanakan sebab-sebab, dimana pada saat yang sama seorang hamba meyakini sebab-sebab itu sendiri tidak memberikan manfaat atau mudharat, kecuali dengan perintah dari "penyebab segala sebab", yaitu Allah swt. Jika suatu persoalan itu mudah, maka itu berkat kemudahan dari-Nya, sebaliknya bila sulit, maka itu juga dengan takdir-Nya.

Sahl bin 'Abdullah At-Tusturi ra berkata, "Barangsiapa yang mencela sebab, berarti mencela sunnah. Barangsiapa yang mencela tawakal, berarti telah mencela imam. Tawakal adalah sikap yang ada pada Nabi saw, sedangkan mengupayakan sebab-sebab merupakan sunnah beliau saw. Barangsiapa yang mengikuti sikap beliau, janganlah meninggalkan sunnahnya." 135

Betapa butuhnya kita hari ini kepada teladan Nabi saw dalam seluruh aspek kehidupan. Dia adalah manusia jujur yang tidak pernah berbicara dengan hawa nafsu. Allah swt berfirman :

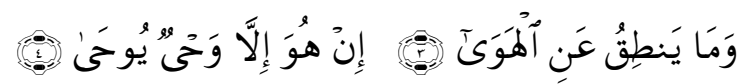

Artinya : "Dan Tiadalah yang diucapkannya itu (Al-Quran) menurut kemauan hawa nafsunya. Ucapannya itu tiada lain hanyalah wahyu yang diwahyukan (kepadanya)." [An Najm : 3-4]

Metode tibbun nabawi memberikan banyak mukjizat dalam menyembuhkan berbagai penyakit yang menimpa badan, yang tidak diketahui oleh pakar-pakar kedokteran di seluruh dunia. Setelah mengetahui bahwa Nabi saw pernah memberikan resep penyembuhan berbagi macam penyakit yang tidak terobati, ia mempraktikkannya, sehingga diperolehlah kesembuhan yang pasti. Para dokter hingga zaman sekarang mengaku fakta ini, sehingga mereka masuk Islam, menyatakan kepatuhan kepada Rabb semesta alam dan bersaksi secara sungguh-sungguh bahwa tidak ada sembahan yang benar selain Allah dan bahwa Muhammad adalah Rasul Allah.

${ }^{134}$ Diriwayatkan oleh Bukhari dalam At Thibb (5357/5356) bab III : Asy syîfâ' fì Tsalatsin. Maktabah Kâmîllah, CD ROOM Jakarta, Ridwana Medikita, 2009

${ }^{135}$ Aiman bin 'Abdul Fattah, Asy-Syifa' min Wahyi Khotami 'l-Anbiya', (Solo: Al Qowam, 2005), h. 20 
Thibbun Nabawi adalah fakta. Ia keluar dari pelita kenabian, yaitu dari wahyu yang diberikan kepada Nabi yang tidak berbicara berdasarkan nafsu. Karena itu, tidak ada yang menolaknya selain manusia yang cacat imannya dan rusak fitrahnya, sebagimana orang yang menolak adanya penyembuhan dengan Al-Qur'an yang memang telah dijadikan oleh Allah sebagai penyembuh dan rahmat bagi seluruh alam. Allah swt berfirman :
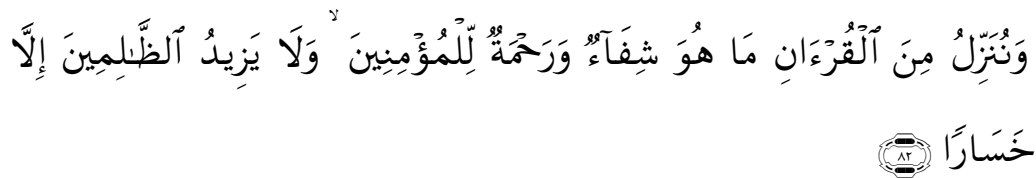

Artinya : "Dan Kami turunkan dari Al Quran suatu yang menjadi penawar dan rahmat bagi orang-orang yang beriman dan Al Quran itu tidaklah menambah kepada orang-orang yang zalim selain kerugian. [Al Isra' : 82]

Di zaman dimana banyak penyakit dan wabah serta menyebar berbagai musibah, kita sangat membutuhkan perenungan mengenai fenomena sakit dan penyembuhan. Agar menjadi jelas bagaimana sikap seorang muslim yang mengharapkan keslamatan tanpa beban. Juga, agar hati kaum muslimin bergantung kepada Allah, Pemberi kesembuhan yang senantiasa menyertai, Yang Maha Penyantun, Maha Penyayang lagi Maha Baik. Fenomena ini harus ditimbangi dangan timbangan ilmiah yang cermat. Sebab, jumlah hukum orang sakit, berobat dan pengobatan mengandung sejumlah macam ibadah dan kondisi yang hanya mampu diraih oleh orang-orang yang memiliki kedudukan yang tinggi disisi Allah swt. Kebanyakan musibah tersebut datang manakala seorang semakin dekat dengan Allah dan lebih mendekat kepada-Nya dengan berbagai macam ibadah.

Tidak ada satu kata pun di dalam Alquran menyebutkan kata ash-shihhah dan al'afiah, tetapi Alquran menyebutkan perkataan syifa' yang berarti kesembuhan (dari sakit), dan pengobatan (menuju kesembuhan dari keadaan sakit). Kata syifa' disebut tiga kali dalam Alquran, yaitu surat Yunus ayat 57, surat al-Isra; ayat 80, dan surat Fushilat ayat 69. Disebutkan bahwa di samping sebagai petunjuk Al Qur'an juga dinyatakan sebagai obat yang menyembuhkan. Allah berfirman:

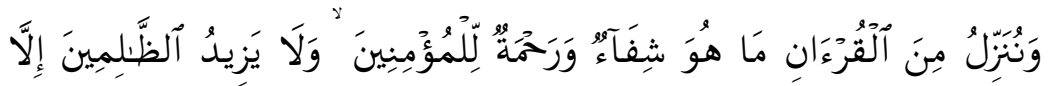


Artinya : "Dan kami turunkan dari Al Quran suatu yang menjadi penawar dan rahmat bagi orang-orang yang beriman dan Al Quran itu tidaklah menambah kepada orang-orang yang zalim selain kerugian. (Al Isra : 82)

Dari ayat ini dapat dipahami bahwa Al Qur'an sebagai penyembuh hanya kepada orang yang beriman secara Islam. Non muslim dikategorikan sebagai orang-orang lalim, otomatis tidak sehat. Dengan demikian, yang dimaksud sehat atau sakit dalam ayat ini bersifat rohaniah. Secara fisik orang dikatakan sehat tetapi secara rohaniah belum tentu dikatakan sehat. Ukuran sehat atau sakit terletak pada iman secara Islam. Tipologi kesehatan yang demikian ini secara lebih eksplisit, yaitu penyakit hati, kata lain dari rohani, disebutkan kembali dalam ayat berikut:

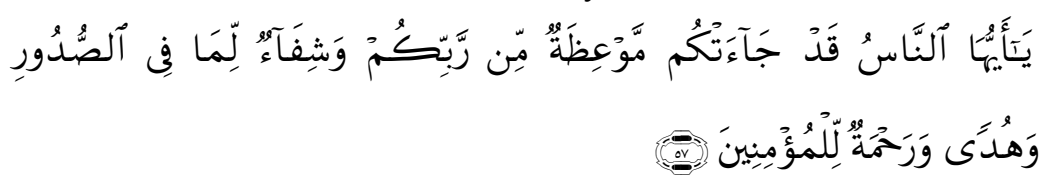

Artinya : “Hai manusia, Sesungguhnya Telah datang kepadamu pelajaran dari Tuhanmu dan penyembuh bagi penyakit-penyakit (yang berada) dalam dada dan petunjuk serta rahmat bagi orang-orang yang beriman." (Yunus :57)

Selanjutnya, Al Qur'an memberi petunjuk bahwa madu lebah mengandung obat. Allah berfirman:

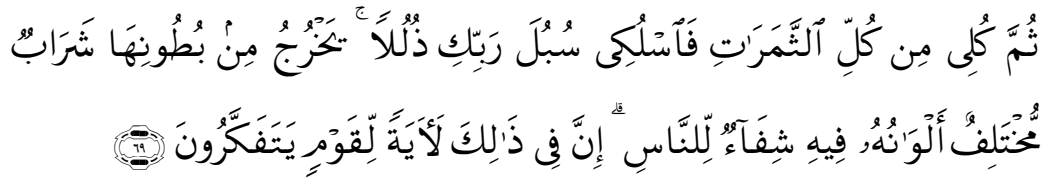

Artinya : "Kemudian makanlah dari tiap-tiap (macam) buah-buahan dan tempuhlah jalan Tuhanmu yang Telah dimudahkan (bagimu). dari perut lebah itu ke luar minuman (madu) yang bermacam-macam warnanya, di dalamnya terdapat obat yang menyembuhkan bagi manusia. Sesungguhnya pada yang demikian itu benar-benar terdapat tanda (kebesaran Tuhan) bagi orang-orang yang memikirkan." (An Nahl : 69)

Dari ayat ini dapat diambil pengertian bahwa kata syifa' mengandung pengertian general (jami'-mani'), yaitu sehat secara umum, bisa sehat secara jasmani maupun sehat secara rohani. Justifikasi sehat dari ayat itu bukan hanya orang beriman secara islami, melainkan manusia secara umum tanpa memandang keimanan seseorang. Rasionalitas dari ayat ini Al Quran bisa 
dijadikan penyembuh dari sakit jasmani maupun rohani, orang beriman maupun orang tidak beriman. Atas dasar iman yang mantab terhadap firman Allah bisa dirumuskan teori dasar (grand theory) bahwa Al-Qur'an adalah penyembuh dari sakit manusia.

Dari rumusan teori yang bersifat universal ini kemudian dioperasionalkan oleh Rasulullah saw, bahwa setiap sakit itu ada obatnya. Teknis pengobatannya bermacam-macam antara lain sebagaimana disebutkan dalam hadis berikut:

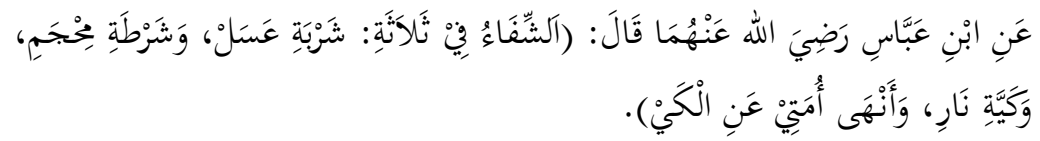

Artinya : "Kesembuhan itu terletak pada tiga hal, yakni minum madu, sayatan alat bekam, dan 'kay' dengan api, sesungguhnya aku melarang umatku dari 'kay'136" 137

Pola hidup sehat ada tiga macam. Yang pertama, melakukan hal-hal yang berguna untuk kesehatan; kedua, menghindari hal-hal yang membahayakan kesehatan; ketiga, melakukan hal-hal yang dapat menghilangkan penyakit yang diderita. Semua pola ini dapat ditemukan dalilnya dalam agama, baik secara jelas atau tersirat, secara khusus atau umum, secara medis maupun non medis (rohani). Allah berfirman:

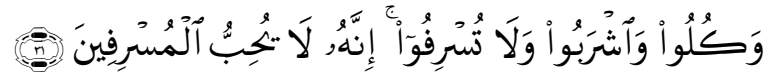

Artinya : makan dan minumlah, dan janganlah berlebih-lebihan. ${ }^{138}$ Sesungguhnya Allah tidak menyukai orang-orang yang berlebihlebihan. (Al A'raf : 31)

Menurut mufasir kontemporer, semacam as-Sa'di, ayat tersebut mencakup perintah menjalani pola hidup sehat dalam bentuk melakukan dan menghindari, yakni mengonsumsi makanan yang bermanfaat untuk tubuh, serta meninggalkan pola makan yang membahayakan. Makan dan minum sangat diperlukan untuk kesehatan, sedangkan berlebih-lebihan harus ditinggalkan untuk menjaga kesehatan. Tuntunan kesehatan fisik dalam agama tentu

${ }^{136}$ Kay adalah cara pengobatan dengan memakai bahan tumbuhan yang dibakar pada titik tertentu dari tubuh, sehingga daya panas yang ditimbulkan menembus permukaan kulit, otot, fascia dan jaringan dibawahnya hingga menimbulkan reaksi pengobatan.

${ }^{137}$ Shohihu al-Bukhori, Ath-Thibb, Juz 1, hal. 5680

${ }^{138}$ Maksudnya: janganlah melampaui batas yang dibutuhkan oleh tubuh dan jangan pula melampaui batas-batas makanan yang dihalalkan. 
saja dibangun diatas pondasi kesehatan rohani, karena ajaran agama bukanlah teori-teori kedokteran.

Contoh-contoh yang disebutkan diatas semuanya memiliki landasan moral, tak murni tuntunan medis. Dalam pandangan agama, kesehatan merupakan kemaslahatan duniawi yang harus dijaga selagi tidak bertentangan dengan kemaslahatan ukhrawi atau kemaslahatan yang lebih besar. Kesehatan, kedokteran dan semacamnya sudah menyangkut kepentingan umum yang dalam pandangan Islam merupakan kewajiban kolektif (fardu kifayah) bagi kaum Muslimin. Sebagai gejala jasmani murni, sehat dan sakit, boleh dibilang tidak secara langsung berkaitan dengan agama. Dalam pandangan agama, sehat belum tentu lebih baik daripada sakit, begitu pula sebaliknya. Sehat dan sakit merupakan dua kondisi yang sama-sama memiliki potensi untuk mendapat label baik atau buruk. Jika manusia bisa mendapat pahala atau dosa dari kondisi sehatnya, maka ia juga bisa mendapatkan pahala atau dosa dari kondisi sakitnya. Di situlah sebetulnya fokus pandangan agama mengenai sehat dan sakit. Selebihnya dari itu, merupakan pengembangan dari prinsip-prinsip moral seperti telah disebutkan di atas. Pada dasarnya, agama sangat menganjurkan kesehatan, sebab apa yang bisa dilakukan oleh seseorang dalam keadaan sehat lebih banyak daripada yang apa yang bisa dilakukannya dalam keadaan sakit. Manusia bisa beribadah, berjihad, berdakwah dan membangun peradaban dengan baik, jika faktor fisik berada dalam kondisi yang kondusif. Jadi, kesehatan fisik, secara tidak langsung, merupakan faktor yang cukup menentukan bagi tegaknya kebenaran dan terwujudnya kebaikan. Namun demikian, posisi kesehatan tetap sebagai sarana bukan tujuan. Tujuan agama adalah tegaknya kebenaran dan terwujudnya kebaikan itu sendiri. Maka, oleh karena itu, dalam sabda-sabda Rasulullah dapat dengan mudah kita temukan janji-janji manis untuk orang-orang yang sakit: bahwa penyakit merupakan penghapus dosa dan mesin pahala yang besar. Dengan demikian, maka jelas sekali bahwa agama mengajarkan hidup sehat, meskipun dibalik itu, yang jauh lebih ditekankan oleh agama adalah bagaimana menggunakan kesehatannya itu untuk sesuatu yang baik. Kondisi terbaik yang paling diimpikan oleh agama bagi kehidupan masyarakat adalah kebaikan dalam kesehatan. Selebihnya dari itu, kesehatan boleh hilang asal kebaikan tetap terjaga, dalam kondisi apapun. Dalam agama Islam kesehatan merupakan penjabaran yang nyata dari rahmat kasih sayang Allah yang meliputi segala-galanya dan mamadai risalah Nabi Besar Muhammad SAW, dan itulah 
sesungguhnya wajah dari Islam. Dari paparan diatas dapat dibuat sebuah kerangka pikir metode dakwah Rasul dalam menyehatkan ummat seperti dibawah ini :

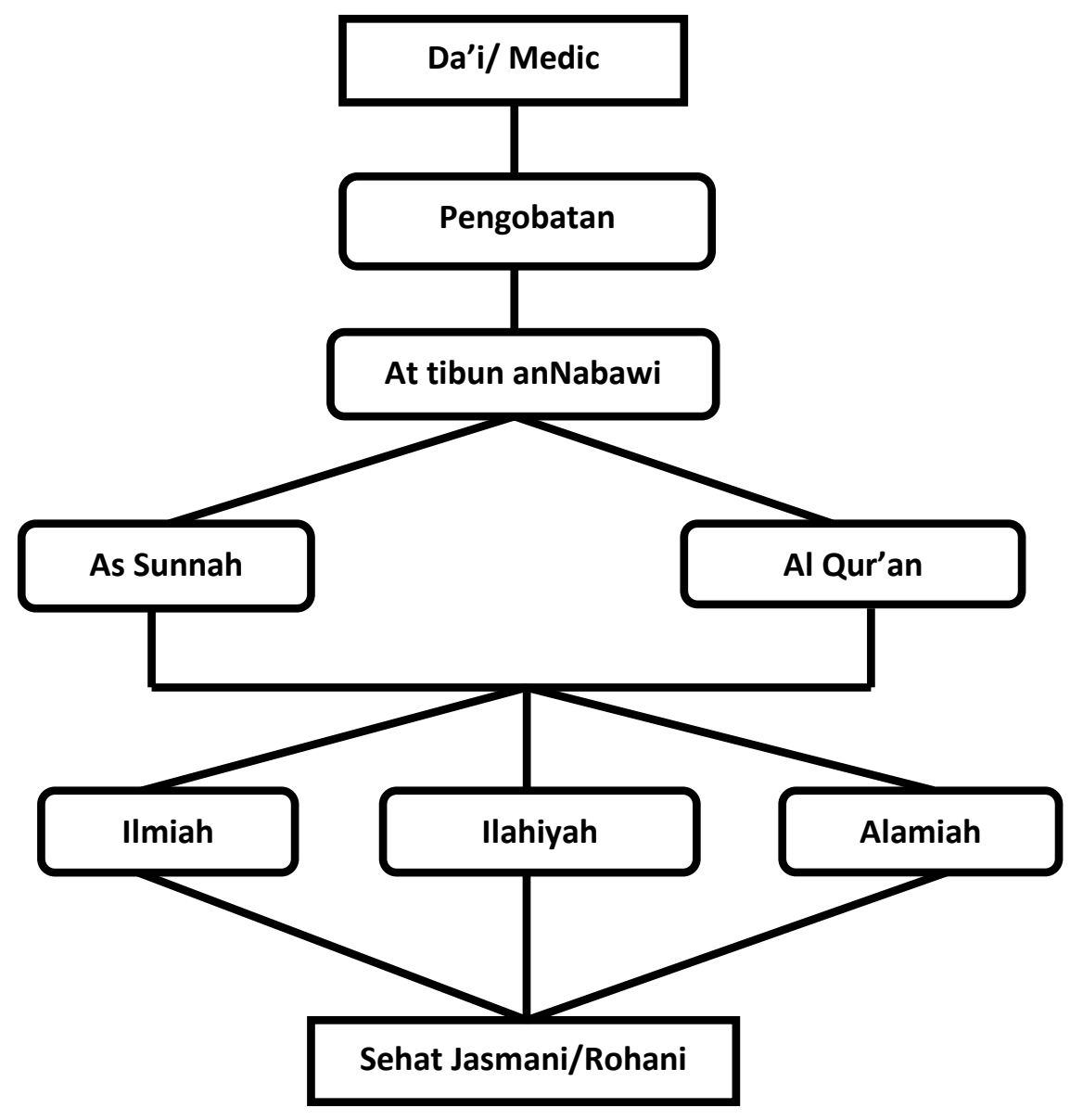

\section{F. Kesimpulan}

Metode dakwah yang direkomendasikan oleh Rasulullah saw dalam bidang kesehatan bukan menyangkut jasadiyah saja namun lebih diutamakan kepada perbaikan ruhiyah (akidah), perbaikan akhlaq, pola hidup yang sehat yang diajarkan Rasul (ittiba'u Rasul) serta kembali kepada Allah As Syafi (Allah yang maha Penyembuh) satu-satunya penyembuh dari segala jenis penyakit dan terhindar jauh dari unsur-unsur TBC (Tahayul, Bid'ah dan Khurofat). ath-Thibb an-Nabawi mengedepankan aspek Ilahiyah, ilmiah dan dibingkai dalam wawasan yang sangat ilmiah. Ditinjau secara umum dalam pengobatan masa ruqyah dan al hijamah terbilang masih banyak juga yang melakukan cara pengobatan diluar syariat Islam, dan mereka 
lebih cenderung kepada hal-hal yang mistik dipenuhi dengan ksyirikan yang menjadikan aqidah ummat semakin jauh dari nilainilai Ilahiyah, dan yang paling miris adalah tidak disadari atau bahkan dengan senaja melakukan hal itu karena keputusasaan yang mereka alami ketika tiada kunjung sembuh sakit yang dideritanya. Kesehatan adalah sangat penting dalam menunjang kehidupan ummat untuk bisa beramal dan berkarya lebih banyak yang tentunya semua itu adalah diniatkan karna Allah, Dialah Semesta yang memiliki ini semua. Salah satu pengobatan yang ada dalam kitab al Thibb al Nabawi yakni ruqyah dan al hijamah yang tenyata sangat luar bisa dalam meyembuhkan berbagi penyakit baik itu jasmani ataupun rohani, bukan hanya itu saja, dengan kesungguhan seorang ahli dalam ruqyah dan al hijamah berarti mereka telah mendakwahkan nilai-nilai Islam kepada pasien sehingga akan terjaga keimananya, aqidah, ibadah dan akhlaknya.

\section{DAFTAR PUSTAKA}

Ahmad, Ismail, Buku Panduan Intibah I, Bogaor; PT. Daarusysyifa, 2007

Ahmad, Amrullah, Dakwah Islam dan Perubahan Sosial, Yogyakarta; PLP2M, 1985

Anshari, Endang Saifudin, Wawasan Islam, Jakarta; Rajawali, 1996

Lin, K.W., Kirchner, J.T., Hepatitis B. American Academy of Family Physician, 2004

M. Saifudin Hakim, Kemana Seharusnya Anda Berobat; Antara Pengobata Medis, Alternatif dan Thibbun Nabawi, Solo: Wacana Ilmiah Press (WIP), 2009

Muhammad Ali Toha Assegaf, Smart Healing; Kiat Hidup Sehat Menurut Nabi saw, Jakarta: Pustaka Al-Kautsar, 2007, Cet. Ke-1

Larry Dossey, M.D, The Exstraodinary Healing Power Of Ordinary Things, Jakarta: Serambi, 2007

Ceramah Asy-Syaikh Shalih bin 'Abdul 'Aziz Alus-Syaikh yang berjudul Ar-Ruqa wa Ahkamuha oleh Salim Al-Jaza iri

Arifin, H.M, Psikologi Dakwah, Jakarta ; Bulan Bintang, 1977

Briliantono M. Soenarwo, Allah Sang Tabib, Al Mawardi; Jakarta, 2009 
Soejono Soemargono, Filsafat Ilmu Pengetahuan, Yogyakarta: Nur Cahaya, 1983

M. Syafaat Habib, Buku Pedoman Dakwah, Jakarta: Wijaya, 1992, Cet. I

Abdul Kadir Munsy, Metode Diskusi dalam Dakwah, Surabaya: Al Ihklas, 1982, Cet. I

Soeleman Yusuf, Slamet Suesanto, Pengantar Pendidikan Sosial, Surabaya: Usaha Nasional, 1981

P. A. Partanto, M. Dahlan Al Barri, Kamus Ilmiah Populer, Surabaya: Arloka, 1994

Sulaiman bin Shalih Al Khuraisi, Pemikiran DR. Yususf Al Qaradhawi dalam Timbangan, Pustaka As syafi'I, 2003, cet. Ke-I.

Yususf Al Qaradhawi, Peran Nilai dan Moral dalam Perekonomian Islam, Rabbani Press, 1997, ct. ke I

Khamami Zada, "Dakwah Transformatif: Mengantar Da'i sebagai Pendamping Masyarakat" dalam, http://www.lakpesdam.or.id/publikasi/116/dakwahtransformatifmengantar-dai-sebagai-pendamping-masyarakat, (download : 7.43 wib, 22 Maret 2015)

Musthafa Malaikah, Manhaj dakwah Yusuf Al Qaradhawi Harmoni antara Kelembutan dan Ketegasan, Pustaka al kautsar, 2001, cet. Ke-I

Aiman bin 'Abdul Fattah, Asy-Syifa' min Wahyi Khotami 'l-Anbiya', Solo: Al Qowam, 2005

Ahmad Zainuddin, , Al Maktabah al-Syamillah CD ROOM, Jakarta, Ridwana Medikita, 2009

Zed, Mestika, Metode Penelitian Kepustakaan, Jakarta; yayasan Obor Indonesia, 2004

Ibnu Hajar al as-Qolani, Bulughul Marom min Adalatil Ahkam, Maktabah ahya' ul maktabah al-Arobiyah Indonesia, $773 \mathrm{H}$ 